\title{
アルコール類を含むアルカリ性浴中で生成する アルミニゥムの陽極酸化皮膜についで
}

\author{
吉 村 長 蔵* 岩 佐 剛 政*

\begin{abstract}
Anodized Film on Aluminum Formed in Alkaline Media
Containing Alcohols
\end{abstract} \\ Studies on Finishing of Aluminum in Alkaline Media (Part 11) \\ Chozo YOSHIMURA and Takamasa IWASA
}

\begin{abstract}
This paper describes the effects of alcohols on anodizing of aluminum in alkaline solutions for the purpose of improving transparency of the anodized film. To a solution mainly composed of $0.1 \mathrm{~mol}$ sodium hydroxide or $0.2 \mathrm{~mol}$ sodium phosphate were added $0.1 \mathrm{~mol}$ polyhydric alcohols (ethylene glycol, glycerine, and sorbitol), and anodizing was performed in the solution. Investigations were made of the effects of additional alcohols on thickness and properties (scratch hardness, corrosion resistance, acid resistance, and alkali resistance) of the oxide film formed by anodizing. The results obtained were as follows: It was found that the addition of alcohols improved these properties in the increasing order of the number of their alcoholic hydroxide groups. Sorbitol had the most remarkable effects on these properties among them. It was suggested that the addition of alcohols prevented the dissolution of formed oxide film and increased the film thickness by co-deposition of electrolytic oxidation products of alcohols.
\end{abstract}

\section{1. 緒言}

アルカリ電解浴に拉けるアルコール類添加の効果につ いては, メチルアルコールの共存は透明度が増すという 報告1) があるが, その他のアルコール類添加の効果や種 々のアルカリ皮膜についての報告はない。ゆえに本報で は, 水酸化ナトリウム, リン酸 3 ナリウムを代表とす るアルカリ基液に，アルコール類（とくにェチレングリ コール, グリセリン, ソルビトールなどの多価アルコー ル）を添加した場合につき，皮膜生成に拈よぼす影響な らびに生成皮膜の諸物性につき検討した。

\section{2. 試験片および電解浴}

\section{2-1 試験片および対㮔}

$99.85 \%$ 純アルミニウム $(3 \times 5 \times 0.04 \mathrm{~cm})$ を用い, 直 流電解を行なった。対極として, 同面積のステンレス (18一8) を用いた。

†アルミニウムのアルカリ性浴処理法の研究（第11 報)，前報(第10報)：金属表面技術，25，187(1974）

* 近畿大学理工学部 (大阪府東大阪市小若江321) Department of Applied Chemistry. Faculty of Science and Engineering. Kinki University.

\section{2-2 試験片の前処理および後処理}

常法にしたがって, 水酸化ナトリウム, 硝酸にて前処 理を行ない, 後処理は電解後 $30 \mathrm{~min}$ 間沸騰水封孔を行な った。

表 1 電 解 条 件

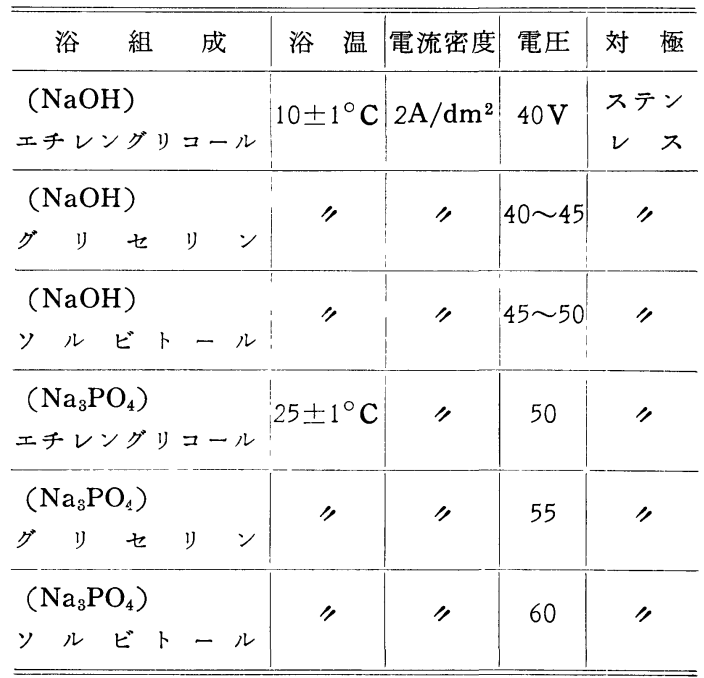




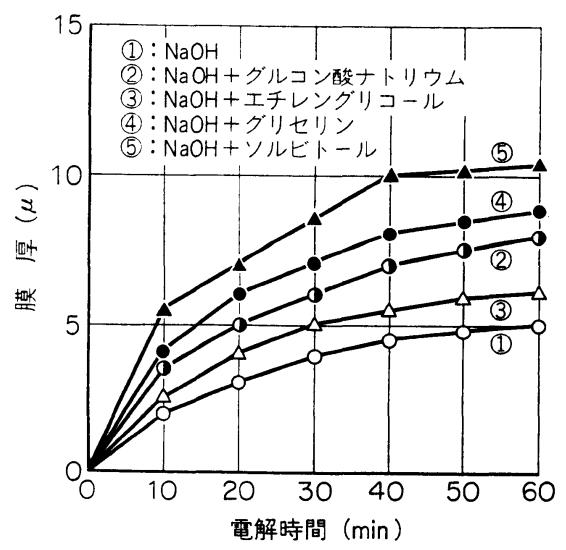

図 1 添加アルコールと膜厚との関係 $(\mathrm{NaOH}$ 浴 $)$

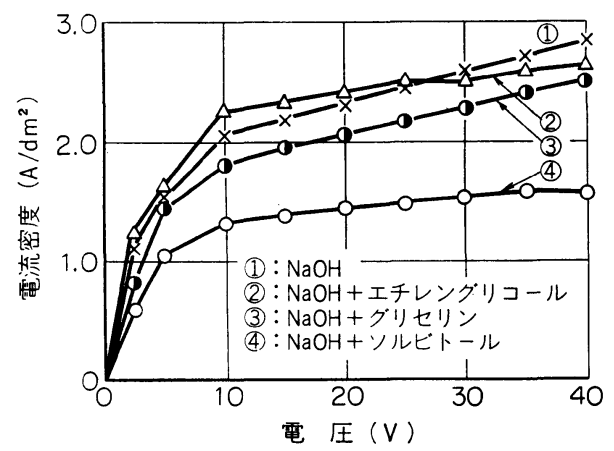

図 3 電流-電圧曲線 $(\mathrm{NaOH}$ 浴)

\section{2-3 電解浴組成}

アルカリ基液として（水酸化ナトリウム；0.1 M，リ 酸 3 ナトリウム；0.2M）を用い，添加アルコール類 はエチレングリコール，グリセリン，ソルビトールを使 用し，各 $0.1 \mathrm{M}$ 添加した浴を電解浴とした。

\section{2-4 電解条件}

電流密度および電解時間は $2 \mathrm{~A} / \mathrm{dm}^{2}, 30 \mathrm{~min}$ を基準と し直流電解を行なった。表 1 亿電解条件を示す。

\section{3. 実験方法}

\section{3-1 電流-電圧曲線および雨流-時間曲線測定法}

電流一電圧曲線の場合, 各電解浴について子 電圧を, $1 \sim 2 \mathrm{~V}$ 間隔で $60 \mathrm{~V}$ 付近まで上昇させ，設定した各電圧 で電流値がほぼ安定する $1 \mathrm{~min}$ 後に電流値を測定し, 電 流-電圧曲線を求めた。

電流-時間曲線は設定した各電圧で，1 min ごとに電 流密度の変化を測定した。

\section{3-2 皮膜試験法}

膜厚はウズ電流式測定器（パーマスコープ）により, 皮膜カタサはマルテンス式ヒッカキカタサ（荷重50 g) 試験器により測定し，耐アルカリならびに耐摩耗試験

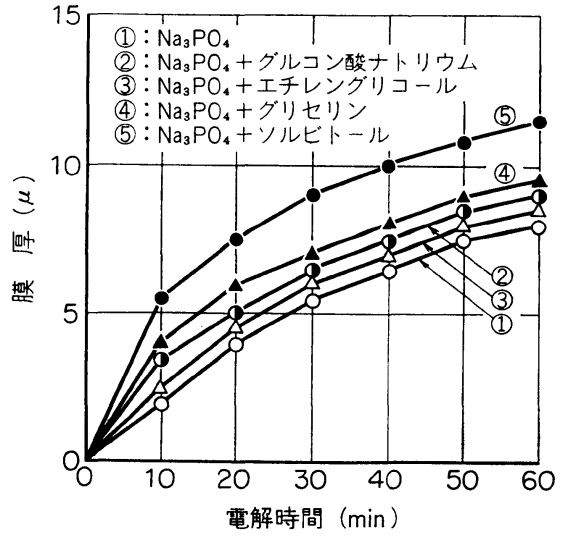

図 2 添加アルコールと膜厚との関係 $\left(\mathrm{Na}_{3} \mathrm{PO}_{4}\right.$ 浴 $)$

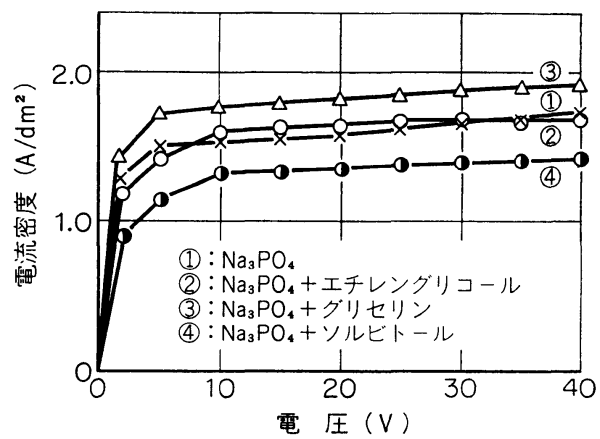

図 4 電流一電圧曲線 $\left(\mathrm{Na}_{3} \mathrm{PO}_{4}\right.$ 浴 $)$

は，JIS H 8601 にて，耐酸性試験は10\%硫酸 $\left(50 \pm 1^{\circ} \mathrm{C}\right)$ 浴に 5 min 浸セキし皮膜の溶解量より測定を行なった。

\section{3-3アルミニウム溶出量試験法}

浴温 $\left(50 \pm 1^{\circ} \mathrm{C}\right)$ のアルカリ単独浴とアルコール類添 加浴に, $1 \mathrm{~min}, 5 \mathrm{~min}, 15 \mathrm{~min}$ 浸セキして溶出量を求 めた。

\section{4. 実験 結果}

\section{4一1アルコール類添加による膜厚の変化}

4-1-1 水酸化ナトリウム浴の場合

アルコール類（エチレングリコール，グリセリン，ソ ルビトール）を添加することにより，水酸化ナトリウム 単独浴より膜厚が厚くなる（図 1)。

4-1-2 リン酸 3 ナトリウム浴の場合

4-1ー1 と同様の結果を得た（図 2)。アルコール類 添加の効果は, ソルビトール>グリセリン>エチレング リコールの順に膜厚が厚くなる。またアルコール類の添 加量を変光電解を行なった結果, 添加量に比例し膜厚は 厚くなる傾向を認めた。

\section{4-2 電流一電圧曲線}

4-2-1 水酸化ナトリウム浴の場合 


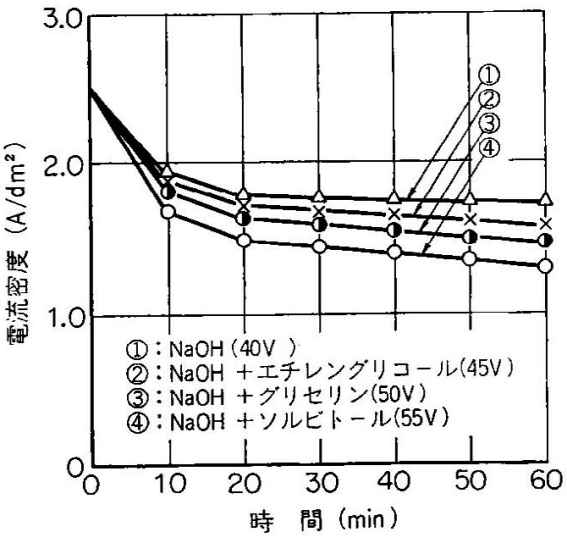

図 5 電流一時間曲線 ( $\mathrm{NaOH}$ 浴)

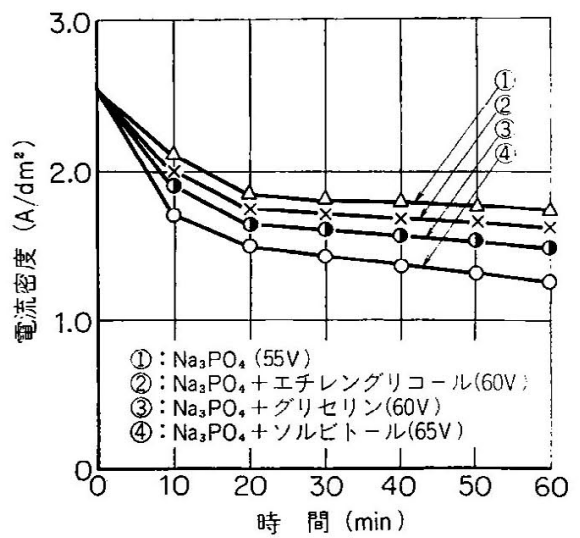

図 6 電流-時間曲線 $\left(\mathrm{Na}_{3} \mathrm{PO}_{4}\right.$ 浴 $)$
アルュール類添加浴について測定したが，10Vまで電 压の上昇にしたがって電流值も急上昇し，10V以後は電 流值は徐々に安定化の傾向を示す。結果を図 3 に示す。

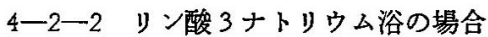

アルコール類添加浴と単独浴の雨者について測定した 結果, 水酸化ナトリウム浴と類似した結果を得た。結果 を図 4 亿示す。

\section{4-3 電流-時間曲線}

4-3-1 水酸化ナトリウム浴の場合

電圧を40Vに 設定して電流-時間曲線を求めたのを図 5 に示す。

\section{4-3-2 リン酸 3 ナトリウム浴の場合}

結果を図 6 に示す。フルコール類添加浴で恃水酸化ナ トリウム浴の場合と同様の結果を得たが，アルコール中 では価数が增すにつれ，電流值は時聞とともに低ドする 現象が人であることを認めた。

\section{4-4 電解時間と膜厚との関} 係

4-4-1 水酸化ナトリウム 浴の場合

傾向は图 1 に示すようにアル コール類を添加することによ り, 単独浴より厚い皮膜が生成 する。ソルビトール添加浴では 単独浴の 2 倍の膜厚を得た。

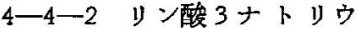
ム浴の場合

水酸化ナトリウム浴の場合と 同様で，傾向を図 2 に示した。 图1，2よりアルュール類中で は,ソルビトール>グリセリン >エチレングリニール>アルカ リ基液の順に膜厚が厚くなる。

\section{4-5 カタサ試験結果}

水酸化ナトリウム浴打よびリン酸 3 ナトリウム浴とも に，直流電解で得られた皮膜のヒッカキカタサは，沸騰 水処理により少しく上昇する。またアルカリ単独浴とア ルコール類添加浴の両者については，後者がカタサにす ぐれていることを認めた。またアルコール類中では，価 数の多い順にソルビトール>グリセリン>エチレングリ

コールの添加がカタサを大にすることを䏰めた。

また添加量については，源加源度が高くなるにつれて カタサが增すことが認められた（表 2)。

\section{4一6 耐アルカリ性試騟結果}

アルコール類添加浴で得られた汥膜の 耐アルカリ性 は，単独浴より得られた汥膜よりも良好で放った（表

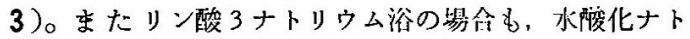
リウム浴と同様の結果を得た。また，アルコール頪中も

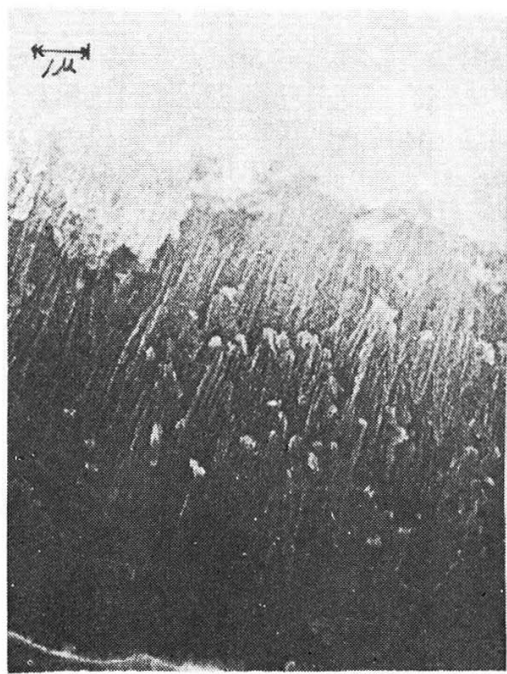

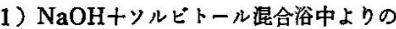
生成皮膘の断面影微鏡写真

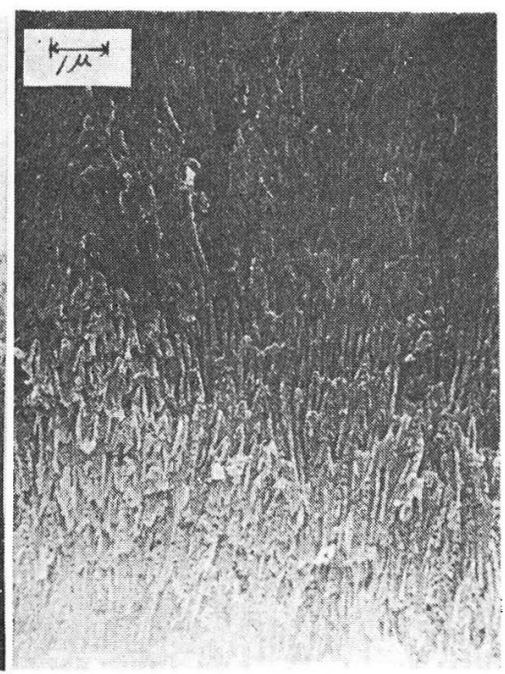

2) $\mathrm{Na}_{3} \mathrm{PO}_{4}+$ ソルビトール混合浴中よ りの生成皮膜の断面湿微鏡写真

写真 1 皮膜 断面 写真 
ソルビトールを添加した浴での皮膜が一番良好な結果を 示した。

\section{4-7 耐酸性試験結果}

単独浴よりもアルコール類添加浴での陽極酸化皮膜の ほうがすぐれた結果を得たが，リン酸 場合にグリセリン添加浴が単独浴よりも耐酸性が劣って いたが理由は不明である。

アルコール類添加皮膜中では, ソルビトールを添加し た浴がほかのアルコール類添加浴に比べ良好な結果を示 した。以上の結果は表 3 に示す。

\section{4-8アルミニウム溶出量試験結果}

水酸化ナトリウム単独浴とアルコール類添加時のアル ミニウム溶出量は，アルコール類添加浴のほうが溶出量 が少ないことを認めた。

リン酸 3 ナトリウム浴の場合も同様で, アルュール類 中では,ソルビトールを添加した場合の溶出量がほかの アルコールよりも少ない。
表 2 アルコール（6価ソルビトール）添加量 によるヒッカキカタサ $\mathrm{NaOH}$ 浴

\begin{tabular}{|c|c|c|c|}
\hline 添加量 & 未 & 処 理 & 沸騰水処理 \\
\hline $0.01 \mathrm{M}$ & & 9.2 & 9.4 \\
\hline $0.1 \mathrm{M}$ & & 9.3 & 9.7 \\
\hline $0.5 \mathrm{M}$ & & 9.4 & 9.8 \\
\hline
\end{tabular}

\begin{tabular}{c|c|c}
$\mathrm{Na}_{3} \mathrm{PO}_{4}$ 浴 & \multicolumn{3}{|l}{ 後処理 } & 未 & 処 理 & 沸騰 水 処 理 \\
\hline 添加量 & 9.0 & 9.2 \\
$0.01 \mathrm{M}$ & 9.1 & 9.3 \\
$0.1 \mathrm{M}$ & 9.4 & 9.6 \\
$0.5 \mathrm{M}$ & & \\
\hline \hline
\end{tabular}

膜厚； $5 \pm 0.5 \mu$

表 3 添加アルコール類と物性（カタサ, 耐アルカリ, 耐酸性)

\begin{tabular}{|c|c|c|c|c|c|c|c|c|c|}
\hline 後処理 & 未 & 処 & 理 & & 沸 & 騰 & 水 & & 理 \\
\hline 浴組成 & 七ッカキカタサ & 耐アルカリ & 耐 & 酸 性 & ヒッカキカタサ & 耐 $ア$ & ルカリ & 耐 & 酸 性 \\
\hline$(\mathrm{NaOH}) 0.1 \mathrm{M}$ & 8.9 & $20 \mathrm{~s}$ & & $26.1 \%$ & 9.0 & & $40 \mathrm{~s}$ & & $6.4 \%$ \\
\hline $\begin{array}{l}(\mathrm{NaOH}) \\
\text { エチレングリコー } \\
\text { ル } \\
\mathrm{C}_{2} \mathrm{H}_{6} \mathrm{O}_{2} \quad 0.1 \mathrm{M}\end{array}$ & 9.0 & 50 & & 23.0 & 9.1 & & 95 & & 3.9 \\
\hline $\begin{array}{l}(\mathrm{NaOH}) \\
\text { グリセリン } \\
\mathrm{C}_{3} \mathrm{H}_{8} \mathrm{O}_{3} \quad 0.1 \mathrm{M}\end{array}$ & 9.2 & 30 & & 19.1 & 9.4 & & 75 & & 3.6 \\
\hline $\begin{array}{l}(\mathrm{NaOH}) \\
\text { ソルビトール } \\
\mathrm{C}_{6} \mathrm{H}_{14} \mathrm{O}_{6} \quad 0.1 \mathrm{M}\end{array}$ & 9.3 & 70 & & 18.8 & 9.7 & & 170 & & 2.4 \\
\hline$\left(\mathrm{Na}_{3} \mathrm{PO}_{4}\right) \quad 0.2 \mathrm{M}$ & 8.7 & 40 & & 16.0 & 9.0 & & 80 & & 6.1 \\
\hline $\begin{array}{l}\left(\mathrm{Na}_{3} \mathrm{PO}_{4}\right) \\
\text { エチレングリコー } \\
\text { ル } \\
\mathrm{C}_{2} \mathrm{H}_{6} \mathrm{O}_{2} \quad 0.1 \mathrm{M}\end{array}$ & 8.8 & 50 & & 15.5 & 9.1 & & 95 & & 2.7 \\
\hline $\begin{array}{l}\left(\mathrm{Na}_{3} \mathrm{PO}_{4}\right) \\
\text { グリセリン } \\
\mathrm{C}_{3} \mathrm{H}_{8} \mathrm{O}_{3} \quad 0.1 \mathrm{M}\end{array}$ & 8.9 & 55 & & 17.1 & 9.2 & & 125 & & 7.9 \\
\hline $\begin{array}{l}\left(\mathrm{Na}_{3} \mathrm{PO}_{4}\right) \\
\text { ソルビトール } \\
\mathrm{C}_{6} \mathrm{H}_{14} \mathrm{O}_{6} \quad 0.1 \mathrm{M}\end{array}$ & 9.1 & 65 & & 16.0 & 9.3 & & 145 & & 4.2 \\
\hline
\end{tabular}

膜 厚; $5 \pm 0.5 \mu$ 素材のカタサ; 7.5

耐酸性; $10 \% \mathrm{H}_{2} \mathrm{SO}_{4}$ 浴に $5 \mathrm{~min}$ 浸セキ 


\section{4-9 顕微鏡観察結果}

おのおのアルカリ単独浴とアルコール類添加浴により 生成した陽極酸化皮膜を，二段レプリカ法拈よび走查型 電子顕微鏡により，それぞれの皮膜表面および断面につ き顕微鏡により観察を行なった。

走査型電子顕微鏡写真より皮膜の構造がチ密であると 考えられることより皮膜のカタサが増す。

顕徽鏡写真 1）水酸化ナトリウム浴にソルビトール 添加, 2）リン酸 3 ナトリウム浴にソルビトール添加 (写真 1)。

\section{5. 結 論}

電流一電圧曲線および電流-時間曲線はアルカリ単独浴 もアルコール類を添加した浴の場合と同じ傾向を示した
ので，皮膜の生長過程は同様であると考えられる。

アルコール類中では, ソルビトールの添加がもっとも 皮膜生成に効果があった。

アルコール類を添加することによりアルカリ単独浴よ りも厚い皮膜を得るのは, アルコールにより陽極酸化皮 膜の溶解がある程度抑制され膜厚が増加するものと考兄 られる。

皮膜のカタサ, 耐アルカリ性, 耐酸性もアルコール類 を添加することにより向上するが，とくにアルコールの 価数の多いもの, 本実験についてはソルビトールの添加 がもっとも効果があった。（1973ー10-18 受理）

\section{文献}

1) Mohammed. I. etc., Pakistan, J.Sci, Ind. Res., 9, 155 (1966)

\title{
アルミニウムの表面状態と累積膜の配列との関係†
}

\author{
出口和夫* ${ }^{*}$ 内藤邦子* ・ 礒山永三** ・村川享男***
Relationship Between Surface Treatments of Aluminum and Orientation of Built-up Films \\ Fundamental Studies on Surface Contaminations of Metals (Part 3) \\ Kazuo DEGUCHI, Kuniko NAITO, Eizo ISOYAMA and Takao MURAKAWA
}

It was observed that the structure of built-up films of stearic acid or stearyl alcohol formed on aluminum by employing Langmuir-Blodgett's technique is markedly influenced by surface conditions. The relationship between the number of built-up layers $(N)$ and the number of times for lifting the specimens up through the monolayer film spread on the water (n) was examined by tracer technique, and it was found that the films were classified into the following two types according to the surface conditions: $N=2 n-1$ and $N=n$. Built-up films of (2n-1) type that can be deposited, for example, on the substrates anodized in ammonium borate or electropolished in $\mathrm{HClO}_{4}$ and glacial acetic acid had hydrophobic surfaces. On the contrary, the surfaces of $n$ type films formed on the substrates such as boeh. mite or thick anodized films were hydrophilic. Determining whether the surfaces are hydrophobic or hydrophilic was made by measuring the contact angle or coefficient of friction. However, other built-up film surfaces deposited, for example, on an anodized substrate of less than $2 \mu$ in thickness, showed some intermediate properties, and this was interpreted in terms of irregular orientation of the polar organic compounds in the films.

$\dagger$ 金属の表面污染に関する基礎的研究（第 3 報），前報（第 2 報）：金属表面技術，24，604（1973）

* 上村工業物中央研究所（大阪府枚方市出口） Uemura Kogyo Co. Central Research Laboratory.

** 昭和アルミニウム㧣技術研究部（大阪府堺市海山町） Tech. Res. Laboratory of Showa Alumimum Co.

*** 昭和電工秼軽金属事業部（東京都港区芝大門 1 丁目） Showa Denko Co., Dept. of Light Metals. なお本研究は著者らが大阪市立大学工学部に在籍中に行なわれたものである。 